\title{
OPEN
}

Published online: 27 February 2020

\section{Author Correction: Controlling parameters and characteristics of electrochemical biosensors for enhanced detection of 8-hydroxy- 2 '-deoxyguanosine}

\author{
Aline M. Faria, Elisa B. M. I. Peixoto, Cristina B. Adamo, Alexander Flacker, Elson Longo \& \\ Talita Mazon
}

Correction to: Scientific Reports https://doi.org/10.1038/s41598-019-43680-y, published online 15 May 2019

The original version of this Article contained errors in the spelling of the authors Cristina B. Adamo and Alexander Flacker, which were incorrectly given as Cristiane B. Adamo and Alexandre Flacker respectively. These errors have now been corrected in the PDF and HTML versions of the Article, and in the accompanying Supplementary Information file.

\begin{abstract}
(c) (i) Open Access This article is licensed under a Creative Commons Attribution 4.0 International (c) License, which permits use, sharing, adaptation, distribution and reproduction in any medium or format, as long as you give appropriate credit to the original author(s) and the source, provide a link to the Creative Commons license, and indicate if changes were made. The images or other third party material in this article are included in the article's Creative Commons license, unless indicated otherwise in a credit line to the material. If material is not included in the article's Creative Commons license and your intended use is not permitted by statutory regulation or exceeds the permitted use, you will need to obtain permission directly from the copyright holder. To view a copy of this license, visit http://creativecommons.org/licenses/by/4.0/.
\end{abstract}

(C) The Author(s) 2020 